\title{
Population structure of short-beaked common dolphins (Delphinus delphis) in the North Atlantic Ocean as revealed by mitochondrial and nuclear genetic markers
}

\author{
Luca Mirimin • Andrew Westgate • Emer Rogan · \\ Patricia Rosel · Andrew Read · Jamie Coughlan • \\ Tom Cross
}

Published online: 10 February 2009

(C) Springer-Verlag 2009

\section{Erratum to: Mar Biol}

DOI 10.1007/s00227-008-1120-y

The authors' given name and family name was erroneously transposed. Please find below the correct order.

Luca Mirimin - Andrew Westgate · Emer Rogan · Patricia Rosel $\cdot$ Andrew Read $\cdot$ Jamie Coughlan $\cdot$ Tom Cross

The online version of the original article can be found under doi: 10.1007/s00227-008-1120-y.

L. Mirimin $(\bowtie) \cdot$ E. Rogan · J. Coughlan · T. Cross

Department of Zoology, Ecology and Plant Science,

University College Cork, Distillery Fields,

North Mall, Cork, Ireland

e-mail:1mirimin@gmail.com

\section{A. Westgate}

Department of Biology and Marine Biology,

University of North Carolina Wilmington,

601 South College Road, Wilmington, NC 28403, USA

P. Rosel

National Marine Fisheries Service,

646 Cajundome Blvd, Lafayette, LA 70506, USA

\section{A. Read}

Duke University Marine Laboratory,

Nicholas School of the Environment and Earth Sciences,

Beaufort, NC 28516, USA 